\title{
Effect of Water Stress on the Seedlings Growth of Acacia Tortilis Subsp. Raddiana in Nursery in Sahelian Zone, Niger
}

\author{
Ishmael Bio Yandou, \\ Habou Rabiou, \\ Faculty of Agricultural sciences, University of Diffa, Niger \\ Idrissa Soumana, \\ National Institute of Agricultural Research of Niger, Niamey \\ Abdou Laouali, \\ Faculty of Agricultural sciences, University of Diffa, Niger \\ Ali Mahamane, \\ Faculty of Agricultural sciences, University of Diffa, Niger \\ Faculty of sciences and technics, \\ Abdou Moumouni University of Niamey, Niger
}

Doi:10.19044/esj.2020.v16n21p228 URL:http://dx.doi.org/10.19044/esj.2020.v16n21p228

Abstract

The characteristic dominance of Acacia tortilis species in the Sahel plays a major ecological and economic role for its populations. However, in recent years, the high pastoral pressure has compromised the natural regeneration of the species and it becomes therefore important to investigate the effect of substrate and water stress on the growth of A. tortilis plants in nurseries. An experimental design made of 72 seedlings divided into 4 treatments with different proportions of substrate and watering was put in place. During the six months study, 3 seedlings were destroyed every month, and growth parameters were measured. These include the height, diameter at the collar, pivot length and diameter, number and length of lateral roots, number of nodes, number of branches, number of leaves and number of spines. Results show that the height, the collar diameter, the pivot diameter, total number of roots, number of lateral roots, number of branches, number of leaves are significantly different among treatments. The substrate containing $1 / 4$ manure and 3/4 sand + watering twice a day recorded the best growth height $(112.1 \pm 4.4 \mathrm{~cm})$; number of branches (39.3 \pm 24.2$)$; leaf biomass $(301.67 \pm 97.99 \mathrm{~g})$ and total number of roots $(34 \pm 1.7)$ after 6 months of followup. The average root pivot length of $\operatorname{Tr} 4$ treatment seedlings $(115.5 \pm 18.2 \mathrm{~cm})$ is 4 times greater than their average height during the 6-month follow-up. The 
average root pivot length of $\operatorname{Tr} 4$ treatment seedlings is 4 times greater than their average height during the 6-month follow-up. After 3 months in nursery, the substrate containing sand only + watering once a week ensures a good development of the rooting root system to young seedlings, allowing them to better explore soil horizons. Hence, for a reforestation program, the substrate containing sand only + watering once a week is the best suited.

Keywords: Acacia tortilis, Water stress, Growth, Nursery, Niger

\section{Introduction}

Climate aridity combined with anthropogenic factors such as agricultural clearing, overgrazing, timber and handicraft stakes, timber service and energy, bushfires are causing forest degradation including those of the protected area (Boulain, 2004, Sambou, 2004, Ozer and Ozer, 2005, Noumi, 2010, Vroh Bi Tra et al., 2010, Gonzalez et al., 2012). However, forest resources play an extremely important role in the ecological and socioeconomic life of rural populations, particularly in the Sahelian area. Acacia tortilis is one of the most currently exploited species in the Sahel and is a keystone species in the arid and Saharan areas of Africa (Munzbergova et al., 2002; Andersen et al., 2007a; Andersen et al., 2007b; Noumi et al, 2012). It plays an important role in improving microclimatic factors in its ecosystem (Abdallah et al., 2008). The positive impact of the species is mainly due to improving soil water and nutrient availability (Bowie et al., 2004; Abdallah et al., 2008; Abdallah et al., 2012; Fterich et al., 2012). The species is used in human food, traditional pharmacopoeia, livestock feed, energy wood and timber (Salif, 2001; Grouzis and Le Floc'h, 2003; CEIBN, 2008). Populations exert a high pressure on the species for different categories of uses. One of the main threats to the species is breeding of small ruminants. Leaves, branches, and fruits are well appetizerd by animals (Grouzis and Le Floc'h, 2003, Noumi, 2010). Fruit collection is also a lucrative activity in this area with the result that the seminal edaphic bank will impoverish. The species young plants are grazed daily by the animals (El Ayadi, 2013). The structure and dynamics of the settlement of $A$. tortilis in the natural environment and developed sites are too disturbed (Diouf et al., 2004; Noumi et al., 2010). Throughout the Sahelian area, stands of the species are dominated by adult individuals. Young plants that can secure the future of the stands are absent and the regeneration of the species is compromised (Noumi, 2010). These anthropogenic factors are compounded by particularly difficult climatic factors in the Sahelian area (Diouf et al., 2013). In this area, the rainy period of the year barely exceeds 3 to 4 months (Laminou, 2009; CNEDD, 2011). Vegetation is subject to permanent stress conditions. Most natural seedlings do not exceed their first year. Indeed, A. tortilis spreads its fruits in April, shortly before the rainy 
season (Diouf et al., 2013). They fall to the ground and, as soon as the first rains soak up which induces a strong germinative response (Arbonnier, 2004). But in the Sahelian area, a month can elapse between the first and second rain, with most sprouted seeds withering under water stress (Rabiou et al., 2015). Natural stands degradation of $A$. tortilis reaches the level of irreversibility and where natural regeneration cannot lead to restoration, in the medium term, the use of so-called rehabilitation techniques becomes a necessity, even a major obligation (Benbada, 2013). Thus, the mastery of the regeneration of local woody species such as $A$. tortilis is a prerequisite for sustainable management of arid and semi-arid ecosystems in West Africa (Amani et al., 2015). Controlling the germination and growth monitoring of nursery plants is essential. On the one hand, it ensures better management of the native species selection of, given their possible success (drought tolerance) at the improving agroforestry systems. On the other hand, it increases the chances of success and minimizing the cost of reforestation. In this sense, several works have been carried out on other woody species in Niger but there is no significant one on A. tortilis. This research is aiming to investigate the nursery growth of Acacia tortilis seedlings under different substrate proportions and water stress conditions.

\section{Materials and methods}

\subsection{Experimental site and seed treatment}

The tests were conducted in the experimental site of the Faculty of Agronomic Sciences of the University of Diffa located at $13^{\circ} 18^{\prime} 43,5^{\prime \prime} \mathrm{N}$ and $12^{\circ} 35^{\prime} 21,8^{\prime}$ 'E (Figure 1).

The pods of Acacia tortilis collected on physically healthy seeds in the village of Bitoa in the department of Gouré were unshelled manually. Seeds were treated by soaking them in the concentrated sulphuric acid solution $(95 \%)$ and then left for 1 hour. After it, they were washed in a tap water during 10 - 15 minutes to remove any trace of acid and then placed in petri dishes for pre-germination. This operation allows synchronized germination in all pots after sowing (Figure 3, 4,5).

\subsection{Experimental design and Data collection}

The experimental design is a total randomization of seventy-two pots (72 pots) composed of four (4) blocks and three (3) repetitions (ie 18 pots per treatment). The treatments applied are:

- Treatment 1: substrate containing 1/4 manure and 3/4 sand + watering twice a day;

- Treatment 2: substrate containing 1/4 manure and 3/4 sand + watering once a week;

- Treatment 3: substrate containing sand only + watering twice a day; 
- Treatment 4: substrate containing sand only + watering once a week.

- The sowing was carried out on 04 April 2017 in 72 empty bags 65.5 $\mathrm{cm}$ high and $97 \mathrm{~cm}$ in diameter to take account of the evolution of the root system during the study. To have a synchronized germination in all the pots, the seeds were subjected to a pre germination in petri dishes in the laboratory. In each pot, five (5) of these seeds have been sown but only one plant is left to emergence. The sighting lasted six (6) months.

The pots were exposed to sunlight at an average ambient temperature of $34.05 \pm 4.74{ }^{\circ} \mathrm{C}$. The frequency of watering was 2 times a day (7:30 a.m. and 5 p.m.). Regular watering of the seedlings with $1 \mathrm{~L}$ of water makes it possible to study the amount of biomass produced by the species. On the other hand, the water stress applied to the seedlings (1L per week) is used to know the degree of resistance of the species once planted on the reforestation sites. Weeding was done according to the frequency of appearance of the weeds.

Each month, three (3) pots of each treatment were destroyed, making a total of twelve (12) seedlings. The seedlings were delicately dug up by breaking the clod of sand in which they are rooted, using a controlled pressure of tap water. For each seedling, the following parameters were measured: the height of the seedlings, the diameter at the collar of the stems, the diameter of the pivot of the root system, the number of lateral roots, the length of the pivot, the length of the lateral roots, the number of branches, number of leaves, number of thorns and weight of leaf biomass.

\section{Data processing}

Statistical analyzes were performed with Minitab 18, R 3.0.3 and Xlstat 2018 software. The normality test (Ryan-Joiner test) was performed to verify the normal distribution of the data. The test results showed that the data does not follow the law of normal distribution. The data were subjected to an analysis of variances with the non-parametric Kruskal-Wallis test. An equality of variances test was performed with the Levene test. The Excel spreadsheet was used to generate the different figures for the evolution of the growth of stems and root pivots of seedlings in the nursery.

\section{Results}

\subsection{Root stem and pivot development}

After one month of sowing, the height growth of the seedlings is onequarter (1/4) of that of the root pivot for all the treatment. The average height of seedlings and the length of the root pivot for all treatments is not significantly different $(\mathrm{P}=0.25)$. From the second $(2 \mathrm{nd})$ month, the seedlings of all treatments gradually grow in height and root pivot. By the sixth (6th) 
month, the growth in height is equivalent to that of the root pivot (Table 1). Analysis of these results shows that in the first age of life of these seedlings, it is rather the aerial part that develops, and the underground part takes over from the second month. The average height of the seedlings is significantly higher $(\mathrm{P}=0.012)$ on substrate with organic manure $(112.1 \pm 4.43 \mathrm{~cm}$, 93.9 $\pm 2.02 \mathrm{~cm}, 92.76 \pm 1.77 \mathrm{~cm}$ cm respectively for $\operatorname{Tr} 1, \operatorname{Tr} 2, \operatorname{Tr} 3$ ) (Table 3). On the other hand, the difference is not significant $(\mathrm{P}=0.157)$ for the root pivot growth with the same treatment. But when seedlings are sand-free organic manure $(\operatorname{Tr} 4)$, the growth of the root pivot $(115.53 \pm 18.17 \mathrm{~cm})$ is about 4 times greater than the height growth $(31.2 \pm 7.19 \mathrm{~cm})$.

\subsection{Number of leaves}

The average number of seedling leaves is significantly different in the first three months for any combined treatments $(\mathrm{P}=0.01)$ (Figure $7 \mathrm{~b})$.

In the 1st and 6th month, the seedlings of the T1 and T3 treatments (watered seedlings) produce much more thorns and leaves than those of the T2 and T4 treatments (seedlings under water stress). The figure 5a illustrates the changes in the number of thorns The average number of seedling thorns in all treatments is significantly different during the first three (3) months $(\mathrm{P}=$ 0.05). The seedlings of $\operatorname{Tr} 1$ and $\operatorname{Tr} 3$ treatments (regularly watered plants) have many more thorns than those under water stress ( $\operatorname{Tr} 2$ and $\operatorname{Tr} 4)$ with respective values of $272 \pm 241 ; 107.3 \pm 73.8 ; 68.33 \pm 13.65$ and $44.7 \pm 23.27$ in the first month and $2300 \pm 951 ; 2299 \pm 1094 ; 1176 \pm 817$ and $697 \pm 301$ in the $6^{\text {th }}$ month.

\subsection{Number of branches}

The average production of the branches is significantly different for any combined treatments from the $1^{\text {st }}$ to the $5^{\text {th }}$ month $(\mathrm{P}=0.05)$ (Figure $\left.8 \mathrm{a}\right)$. Furthermore, treatments ( $\operatorname{Tr} 1$ and $\operatorname{Tr} 3)$ whose seedlings are regularly watered have many more branches than those under water stress $(5.7 \pm 5 ; 2.3 \pm 2.1$ in the first month and $39.3 \pm 24.2 ; 45.7 \pm 11$ in the $6^{\text {th }}$ month).

\subsection{Roots number}

The number of roots is higher in the $\operatorname{tr} 1$ and $\operatorname{Tr} 2$ seedlings in the first four months (11.7 \pm 5.1 , respectively; 6.3-6.7 in the 1 st month and $34 \pm 1.7 ; 11 \pm 8.7$ in the $6^{\text {th }}$ month) (Figure. $8 \mathrm{~b}$ ). The test results show a significant difference for the average number of roots in the 1st month and the last three (3) months $(\mathrm{P}<0.05)$. From the 4 th month, development of the root system of the seedlings is observed in the seedlings of treatments regularly watered $(\operatorname{Tr} 1$ and $\operatorname{Tr} 3)$ compared to the seedlings subjected to water stress $(\operatorname{Tr} 2$ and $\operatorname{Tr} 4)$. 


\subsection{Leaf biomass}

Evaluation of fresh leaf biomass of seedlings showed that $\operatorname{Tr} 1$ and $\operatorname{Tr} 3$ treatments produce much more leaf biomass than $\operatorname{Tr} 2$ and $\operatorname{Tr} 4$ treatments after 180 days (Figure 9). After 6 months, the average weights of the fresh leaf biomass of $\operatorname{Tr} 1, \operatorname{Tr} 2, \operatorname{Tr} 3$ and $\operatorname{Tr} 4$ are $58.33 \pm 27.74 \mathrm{~g}, 28.67 \pm 18.04 \mathrm{~g}, 48 \pm 16.52 \mathrm{~g}$ and $19 \pm 10.82 \mathrm{~g}$ respectively. These differences are also significant $(\mathrm{P}=0.05)$.

\subsection{Relation entre le type de substrat et les paramètres de croissance des plantules}

The principal component analysis (PCA) (Figure 10) between the type of treatment and the parameters measured shows that the 2 axes concentrate $95.5 \%$ of total variances. The first axis alone concentrates $80 \%$ and the second axis $15.8 \%$. Axis 1 therefore reflects the opposition that exists between treatments sprayed frequently against those subjected to water stress. This axis also opposes the measured parameters, opposing the diameter of the pivot, the number of branches, the number of leaves, the number of thorns against the height of the seedlings, the length of the pivot, the diameter at the collar, the total number of roots, the number of lateral roots. Axis 2 pits treatments that contain manure against treatments with sand only (without manure).

\section{Discussion}

Study of the juvenile growth of A. tortilis showed that the species has a rhythmic growth. It highlighted the growth of the aerial part and root system of the species. In case of water deficit, the roots synthesize the abscisic acid, conveyed via the conductive vessels to trigger the closure of the stomata (Anonymous, 2009). This leads to a dysfunction of photosynthesis, and therefore a decrease in the production of dry matter in the species. Results show that water stress influences the evolution of the number of leaves, branches, thorns and roots. The effect of substrate fertility on the growth of the species has also been highlighted through the sand and manure mixture. This mixture leads to the formation of aggregates which in turn improve the structure, water retention and availability of nutrients for young seedlings.

Results show that the fertility of the substrate has no effect on the evolution of the number of leaves, branches, and thorns of A. tortilis. On the other hand, growth in height (stem) and length of the root system (root pivot) was recorded in the species because of substrate fertility ( $\operatorname{Tr} 1$ and $\operatorname{Tr} 2)$. Results showed that stem and root pivot growth of the species is dependent on the fertility of the substrate. When it comes to watering, it provides water to keep the A. tortilis seedlings turgescence at the leaf level in case of soil drying. Water also transports nutrients as liquid solution stored in vacuoles. By inflating the cells, the pressure of the water ensures the rigidity of the stems and leaves. Regularly watered seedlings produce more leaves and thorns than 
those under water stress since organic matter is synthesized by leaves and stored in thorns and fruits.

After four (4) months, the density of the species' root system gradually increases at the level of the watered seedlings ( $\operatorname{Tr} 1$ and $\operatorname{Tr} 2)$. The substrate composed of sand and well-decomposed manure watered twice a day $(\operatorname{Tr} 1)$ is conducive to the growth of $A$. tortilis seedlings with a high average height and a high number of branches). The explanation lies in the fact that the mixture of sand and manure ensures the availability of nutrients and good water retention. These results corroborate those obtained by Abdourahamane et al. (2014) on Sclerocarya birrea in Niger; Benmahioul et al. (2010) on seedlings from Pistacia vera L in Algeria; Baghdadi and Sahouli (2003) on Pistacia atlantica plants in Algeria. This average value of the recorded height is higher than that found by Roussel (1995). The Tr1 treatment has consequences on the architecture of the root system of the species. According to Vassal (2003), the rotating root system is often particularly developed in depth in Acacia. The $\operatorname{Tr} 1$ treatment combines all the necessary conditions (water, nutrients) for the proper development of seedlings. Consequently, high leaf gas exchanges (perspiration, photosynthesis) with a good water supply correspond to a relative equilibrium (Kane et al.,1997). These results corroborate those obtained in adult subjects of Balanites aegyptiaca in the wild in Senegal (Bille, 1977), Acacia tortilis in Burkina Faso (Ganaba, 1994) and young plants of Balanites aegyptiaca and A. tortilis in Senegal (Logbo et al., 2013). The root development of $A$. tortilis plants occurs within the first month at the expense of the aerial part regardless of the type of treatment. Seven of these results do not support those findings by Jackson et al. (2000) which claim that the relative importance of the roots depends on the nature and edaphic properties of the site.

After 90 days in the nursery under water stress, A. tortilis can develop a root system (root pivot) capable of prospecting the horizons of the soil in case of planting in natural conditions. The use of this species in reforestation programs could allow sustainable reforestation of natural rangelands, forests, and dune systems in the Diffa region. However, for the success of reforestation actions with this species, local populations have to be associated in the protection of the young plants from domestic animals pressure.

Funding: This work was supported by the Pan-African Agency of the Great Green Wall (APGMV) scholarship funds.

\section{Acknowledgements}

We thank the Pan-African Agency of the Great Green Wall (APGMV) for the grant it has awarded us. We also thank the University of Diffa for the 
multifaceted support it has always provided. Our thanks also go to the people of the villages and technical services for their reception and availability.

Figure 1: Experimental site location

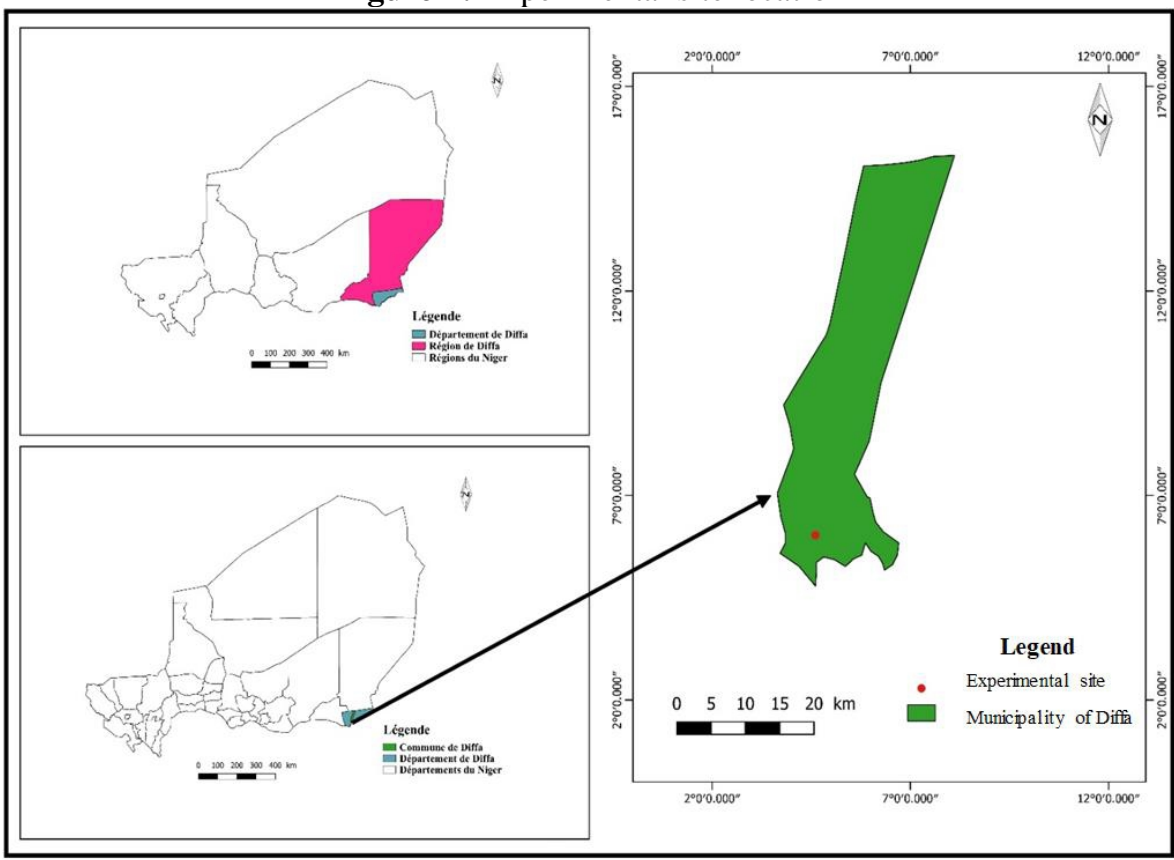

Figure 2 : Ombrothermal curve of the study area

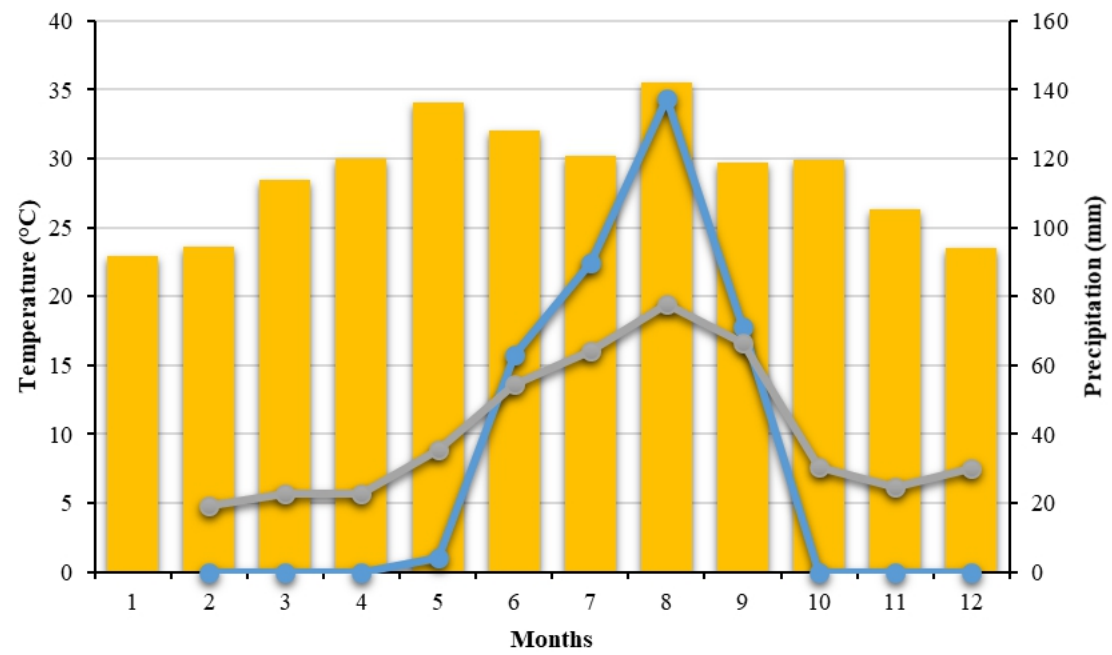

Average monthly temperature $\longrightarrow$ Average monthly precipitation $\longrightarrow$ Monthly average relative humidity 

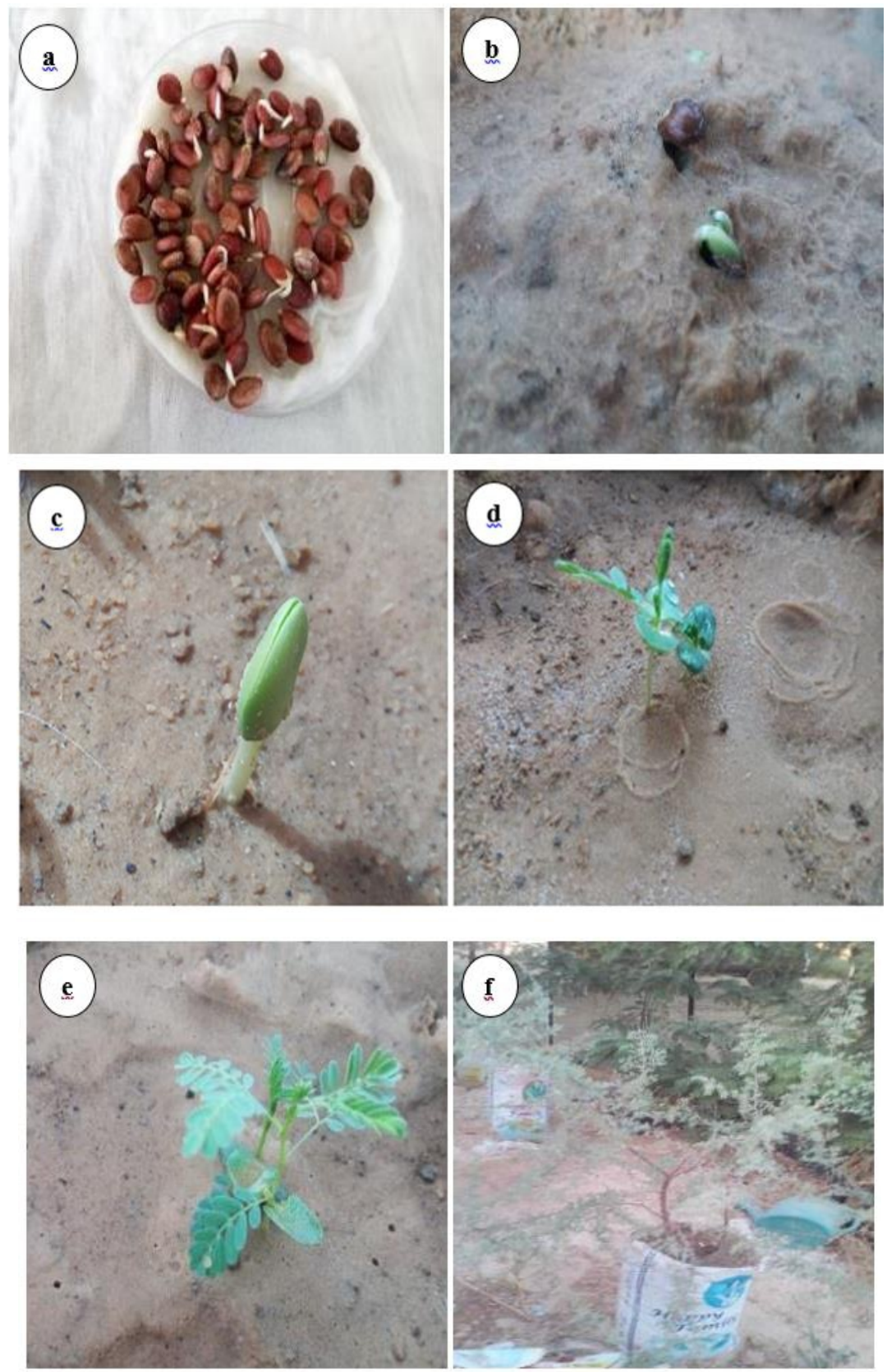

Figure 3: Growth of the seedling of A. tortilis: a: Pregermination of the seed; b: 1 day after sowing; c: 2 days after sowing; d: 5 days after sowing; e: 10 days after sowing; f: 6 months after sowing 


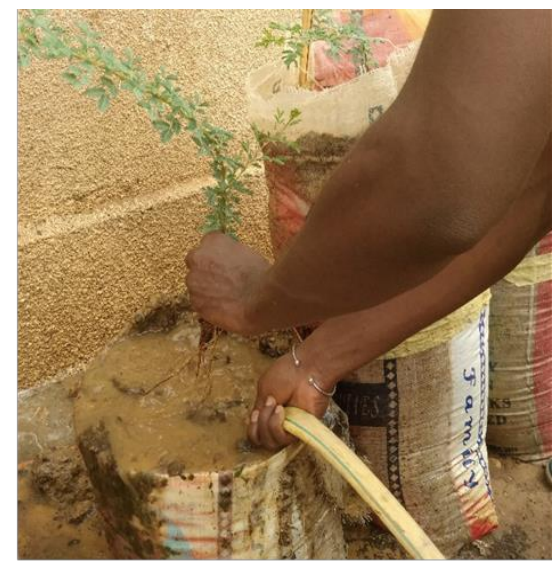

Figure 5: Digging up seedlings in nurseries
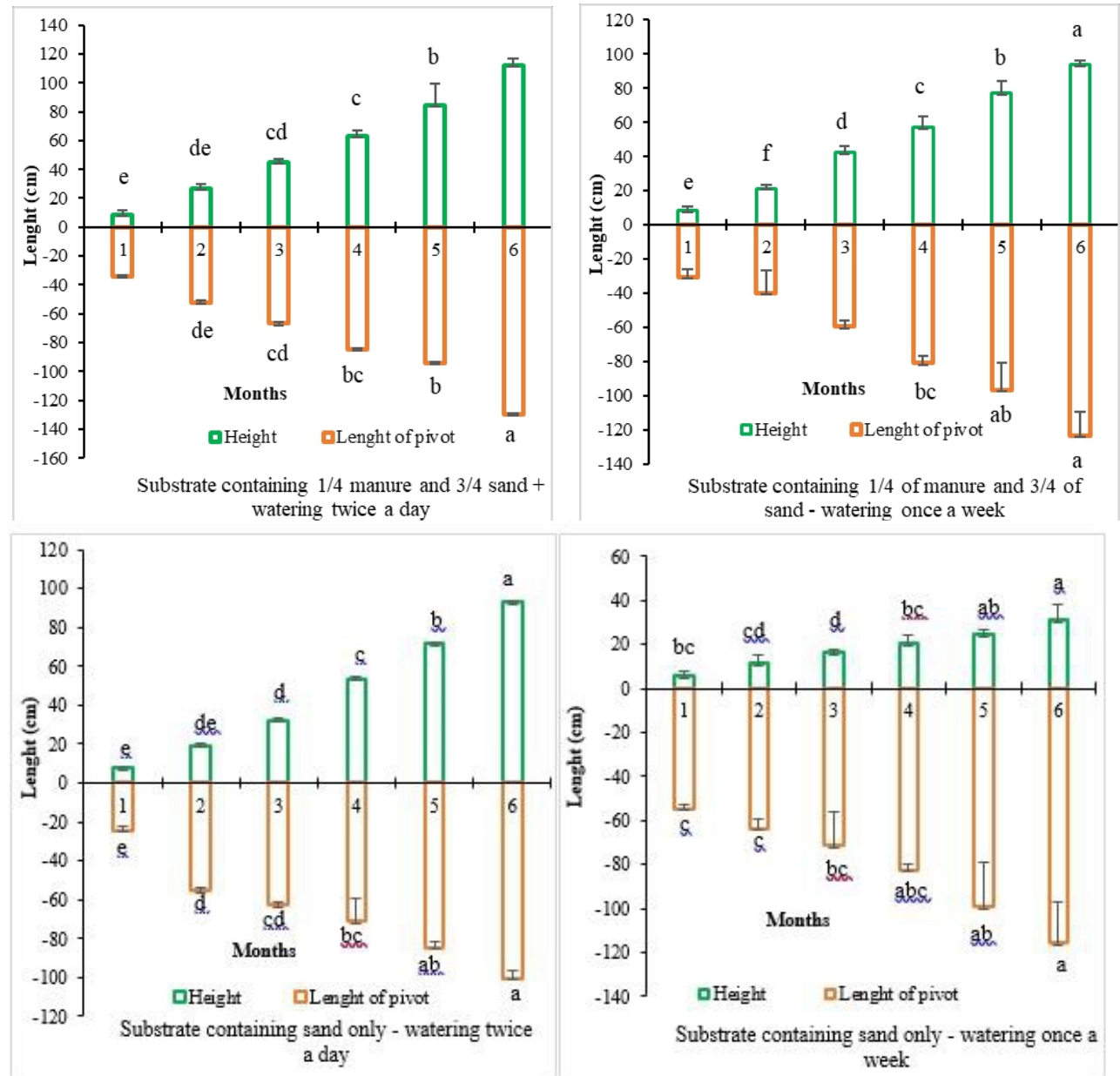

Figure 6: Evolution of the root stem and pivot of seedling 

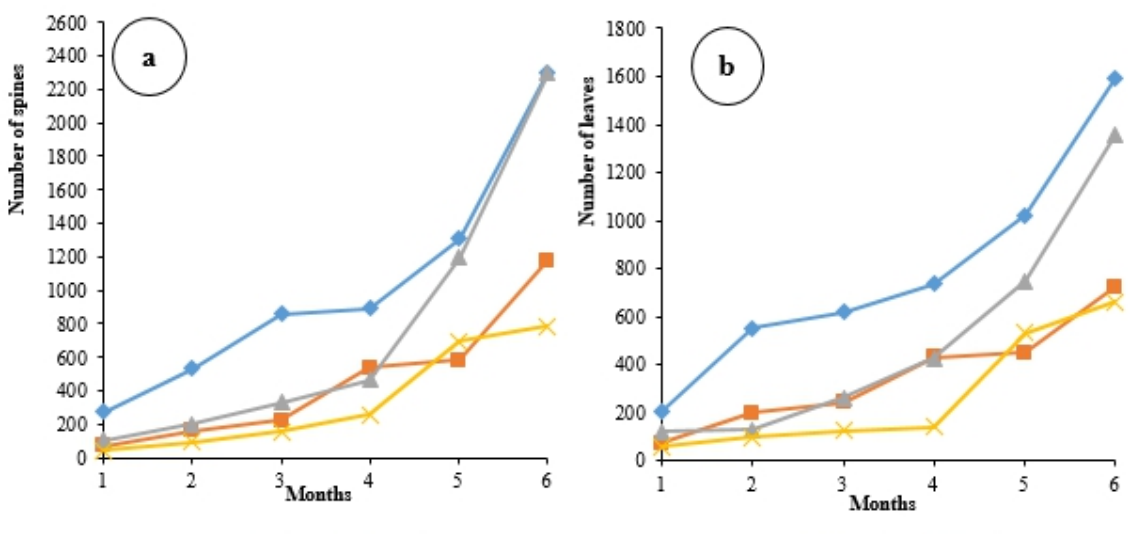

Figure 7: a : Number of spines ; $b$ :Number of leaves
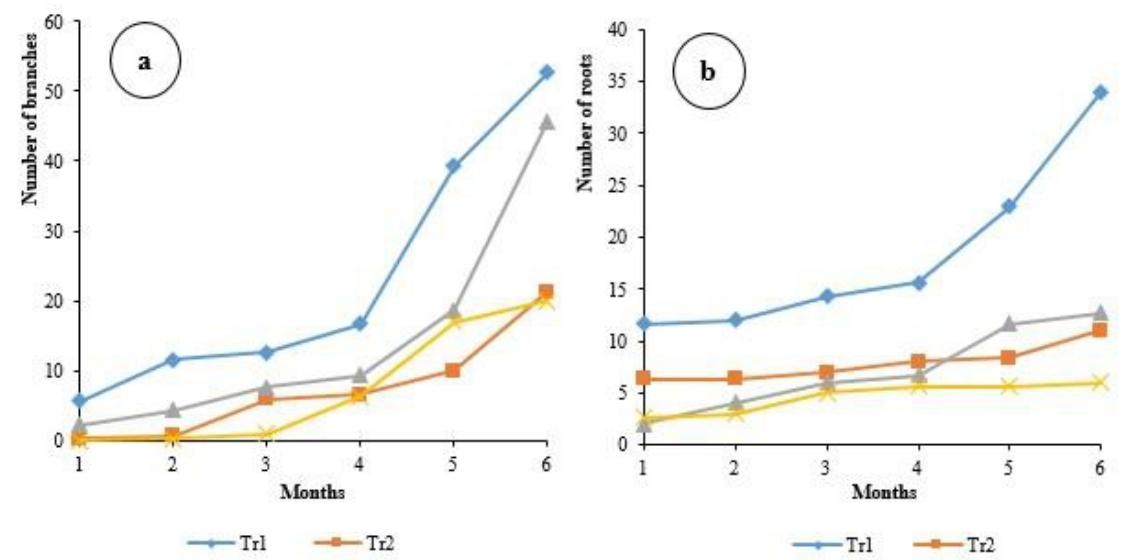

Figure 8: a : Number of branches ; $\mathbf{b}$ :Number of roots

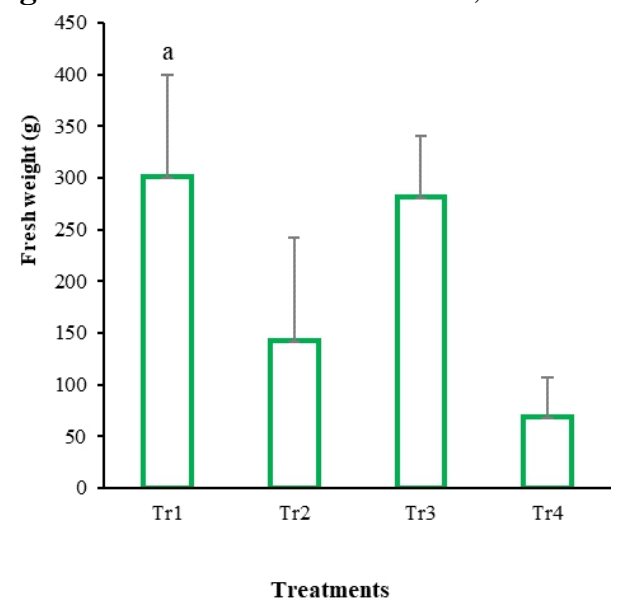

Figure 9 : Fresh biomass 
Double projection diagram $(95,5 \%)$

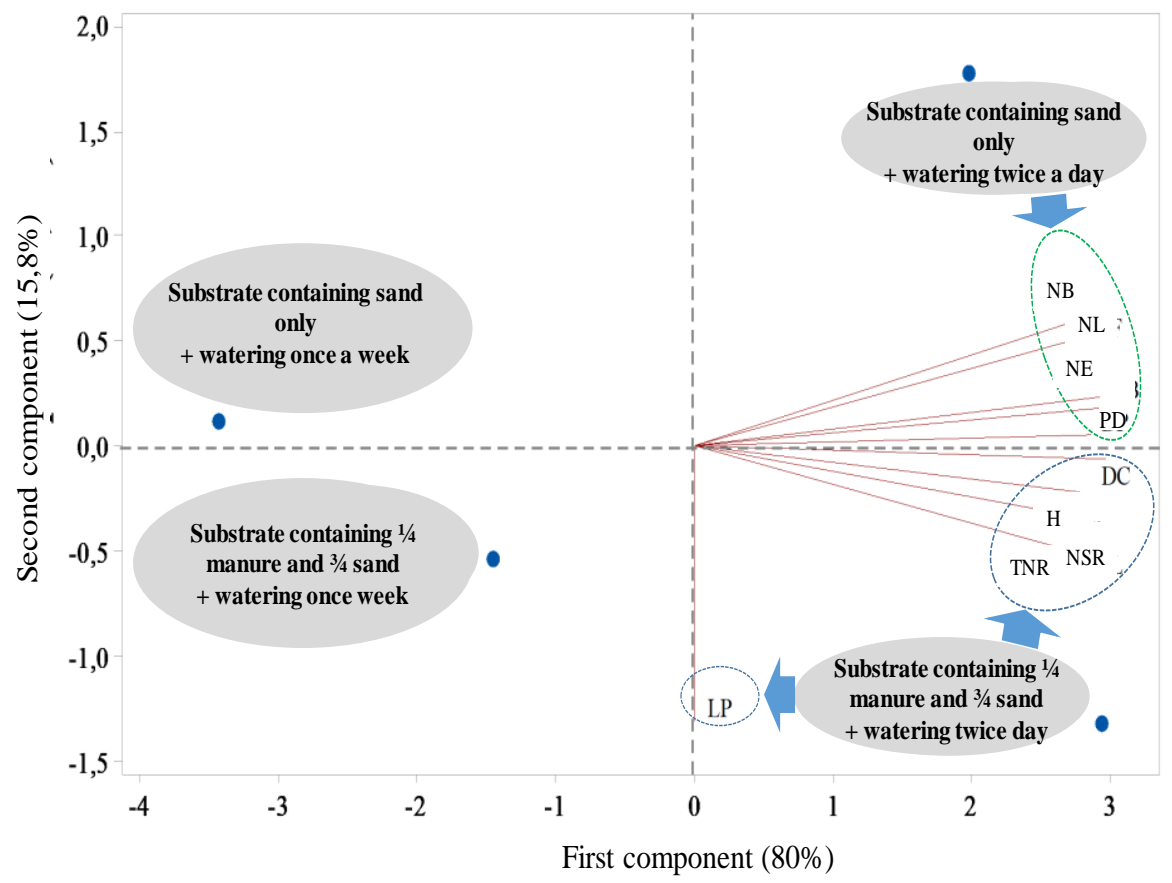

Figure 10: Principal Component Analysis (PCA) Double Projection Diagram

Legend: H: Height; LP: Lenght of pivot; DC: Diameter at collar; PD: Pivot diameter; TNR: Total number of roots; NSR: Number of side roots; NS: Number of spines; NB: Number of branches; NL: Number of leaves. 
Table 1. Average values of measured parameters

\begin{tabular}{|c|c|c|c|c|c|c|c|c|c|c|c|c|c|}
\hline \multirow[b]{2}{*}{ Variable } & \multirow{2}{*}{$\frac{\text { Months }}{\text { Treatments }}$} & \multicolumn{2}{|l|}{1} & \multicolumn{2}{|l|}{2} & \multicolumn{2}{|l|}{3} & \multicolumn{2}{|l|}{4} & \multicolumn{2}{|l|}{5} & \multicolumn{2}{|l|}{6} \\
\hline & & A & $\begin{array}{l}\mathrm{CV} \\
(\%)\end{array}$ & A & $\begin{array}{l}\mathrm{CV} \\
(\%)\end{array}$ & A & $\begin{array}{l}\mathrm{CV} \\
(\%)\end{array}$ & A & $\begin{array}{l}\mathrm{CV} \\
(\%)\end{array}$ & A & $\begin{array}{l}\text { CV } \\
(\%)\end{array}$ & A & $\begin{array}{l}\text { CV } \\
(\%)\end{array}$ \\
\hline \multirow{4}{*}{$\mathbf{H}$} & $\operatorname{Tr} 1$ & $8.9 \pm 2.7 \mathrm{a}$ & 31 & $27.1 \pm 2.7 \mathrm{a}$ & 9.9 & $45.1 \pm 2.1 \mathrm{a}$ & 4.7 & $63.2 \pm 4 a$ & 6.3 & $84.3 \pm 14.8 \mathrm{a}$ & 17.6 & $112.1 \pm 4.4 \mathrm{a}$ & 4 \\
\hline & $\operatorname{Tr} 2$ & $8.1 \pm 2.2 \mathrm{a}$ & 10.1 & $21.4 \pm 2.2 b$ & 33.2 & $42.5 \pm 3.5 \mathrm{a}$ & 8.2 & $56.9 \pm 6.6 \mathrm{~b}$ & 11.6 & $77.4 \pm 6.9 b$ & 8.9 & $93.9 \pm 2 b$ & 2.2 \\
\hline & $\operatorname{Tr} 3$ & $7.6 \pm 2 \mathrm{a}$ & 26.7 & $19.1 \pm 8.1 \mathrm{c}$ & 42.1 & $32.4 \pm 9.1 \mathrm{~b}$ & 28.2 & $53.4 \pm 0.9 \mathrm{c}$ & 1.6 & $71.6 \pm 8 b$ & 11.1 & $92.8 \pm 1.8 b$ & 1.9 \\
\hline & $\operatorname{Tr} 4$ & $5.7 \pm 1.6 \mathrm{a}$ & 9.6 & $11.6 \pm 3.2 \mathrm{~d}$ & 27.5 & $16.3 \pm 2.2 \mathrm{c}$ & 38.5 & $20.4 \pm 3.6 \mathrm{~d}$ & 17.7 & $24.6 \pm 1.8 \mathrm{c}$ & 7.2 & $31.2 \pm 7.2 \mathrm{c}$ & 23.1 \\
\hline \multirow{4}{*}{ LP } & Tr1 & $34.2 \pm 4.7 b$ & 13.7 & $52 \pm 1.8 \mathrm{~b}$ & 3.4 & $66.8 \pm 6 \mathrm{~b}$ & 9 & $84.8 \pm 4.5 \mathrm{a}$ & 5.3 & $94.2 \pm 12.6 \mathrm{~b}$ & 13.4 & $129.7 \pm 5 a$ & 3.9 \\
\hline & $\operatorname{Tr} 2$ & $30.6 \pm 4.8 \mathrm{c}$ & 15.6 & $39.9 \pm 13.4 \mathrm{~d}$ & 33.5 & $59.5 \pm 3.7 \mathrm{c}$ & 6.3 & $80.9 \pm 4.1 b$ & 5.1 & $96.7 \pm 16 \mathrm{a}$ & 16.6 & $123.3 \pm 13.7 \mathrm{a}$ & 11.1 \\
\hline & $\operatorname{Tr} 3$ & $24.3 \pm 1.8 \mathrm{~d}$ & 7.4 & $48.7 \pm 10.3 c$ & 21.1 & $63 \pm 2.1 b$ & 3.3 & $70.9 \pm 12 c$ & 16.8 & $84.5 \pm 3 c$ & 3.6 & $100.3 \pm 3.4 \mathrm{c}$ & 3.4 \\
\hline & $\operatorname{Tr} 4$ & $54.5 \pm 1.7 \mathrm{a}$ & 3.2 & $63.5 \pm 4.1 \mathrm{a}$ & 6.4 & $71.6 \pm 15.2 \mathrm{a}$ & 21.2 & $82.5 \pm 2.3 b$ & 2.8 & $99.2 \pm 20.2 \mathrm{a}$ & 20.4 & $115.5 \pm 18.2 b$ & 15.7 \\
\hline \multirow{4}{*}{ DC } & Tr1 & $0.5 \pm 0.3 \mathrm{a}$ & 54.9 & $0.4 \pm 0.2 \mathrm{a}$ & 38.8 & $0.6 \pm 0.4 \mathrm{a}$ & 62.8 & $0.7 \pm 0.1 \mathrm{a}$ & 19.2 & $1 \pm 0.2 \mathrm{a}$ & 19.8 & $1.3 \pm 0.3 \mathrm{a}$ & 20.2 \\
\hline & $\operatorname{Tr} 2$ & $0.3 \pm 0.1 b$ & 28.9 & $0.2 \pm 0 \mathrm{~b}$ & 19.4 & $0.43 \pm 0.2 b$ & 34.6 & $0.6 \pm 0 \mathrm{a}$ & 5.6 & $0.6 \pm 0.2 \mathrm{a}$ & 25.8 & $0.9 \pm 0.2 \mathrm{a}$ & 21.6 \\
\hline & $\operatorname{Tr} 3$ & $0.3 \pm 0.1 b$ & 40.1 & $0.3 \pm 0.1 \mathrm{a}$ & 30.6 & $0.45 \pm 0 \mathrm{~b}$ & 7 & $0.6 \pm 0.2 \mathrm{a}$ & 26.6 & $0.6 \pm 0.2 \mathrm{a}$ & 42.2 & $1.2 \pm 0.2 \mathrm{a}$ & 18.6 \\
\hline & $\operatorname{Tr} 4$ & $0.3 \pm 0 \mathrm{c}$ & 12.1 & $0.2 \pm 0 \mathrm{~b}$ & 11.8 & $0.16 \pm 0 \mathrm{c}$ & 15.9 & $0.6 \pm 0.2 \mathrm{a}$ & 30.3 & $0.6 \pm 0.2 \mathrm{a}$ & 37.4 & $0.7 \pm 0.1 \mathrm{a}$ & 7.8 \\
\hline \multirow{4}{*}{ PD } & Tr1 & $0.4 \pm 0.3 \mathrm{a}$ & 78 & $0.3 \pm 0.2 \mathrm{a}$ & 47.7 & $0.6 \pm 0.3 \mathrm{a}$ & 57.5 & $0.7 \pm 0.1 \mathrm{a}$ & 12.8 & $1.1 \pm 0.3 \mathrm{a}$ & 24.6 & $1.3 \pm 0.3 \mathrm{a}$ & 18.9 \\
\hline & $\operatorname{Tr} 2$ & $0.2 \pm 0.1 b$ & 38 & $0.16 \pm 0.1 \mathrm{a}$ & 44.7 & $0.4 \pm 0.2 b$ & 36.2 & $0.6 \pm 0 \mathrm{a}$ & 2.4 & $0.7 \pm 0.1 \mathrm{a}$ & 17.2 & $0.9 \pm 0.4 \mathrm{a}$ & 39.4 \\
\hline & $\operatorname{Tr} 3$ & $0.2 \pm 0.1 b$ & 46.8 & $0.16 \pm 0 \mathrm{a}$ & 17.1 & $0.4 \pm 0 \mathrm{~b}$ & 2.7 & $0.6 \pm 0.2 \mathrm{a}$ & 28.2 & $0.6 \pm 0.3 \mathrm{a}$ & 42.7 & $1.3 \pm 0.1 \mathrm{a}$ & 5.7 \\
\hline & $\operatorname{Tr} 4$ & $0.4 \pm 0 \mathrm{c}$ & 9.6 & $0.24 \pm 0 \mathrm{a}$ & 13.6 & $0.3 \pm 0.2 b$ & 73.6 & $0.3 \pm 0.1 b$ & 15.8 & $0.6 \pm 0.3 \mathrm{a}$ & 42.8 & $0.4 \pm 0.1 \mathrm{a}$ & 23.2 \\
\hline \multirow{4}{*}{ TNR } & Tr1 & $11.7 \pm 5.1 \mathrm{a}$ & 44 & $12 \pm 4.4 \mathrm{a}$ & 36.3 & $14.3 \pm 9.9 \mathrm{a}$ & 68.8 & $15.7 \pm 6.1 \mathrm{a}$ & 39 & $23 \pm 13 a$ & 56.5 & $34 \pm 1.7 \mathrm{a}$ & 5.1 \\
\hline & $\operatorname{Tr} 2$ & $6.3 \pm 6.7 b$ & 105.1 & $6.3 \pm 4.5 b$ & 71.2 & $7 \pm 2 b$ & 28.6 & $8 \pm 5.3 b$ & 66.1 & $8.3 \pm 8.4 \mathrm{c}$ & 100.6 & $11 \pm 8.7 b$ & 78.7 \\
\hline & $\operatorname{Tr} 3$ & $2 \pm 1 d$ & 50 & $4 \pm 3 c$ & 75 & $6 \pm 1.7 \mathrm{c}$ & 28.9 & $6.7 \pm 2.9 \mathrm{c}$ & 43.3 & $11.7 \pm 4.7 b$ & 40.5 & $12.7 \pm 1.5 b$ & 12.1 \\
\hline & $\operatorname{Tr} 4$ & $2.7 \pm 0.6 \mathrm{c}$ & 21.7 & $3 \pm 1.7 \mathrm{c}$ & 57.7 & $5 \pm 1 c$ & 20 & $5.7 \pm 5.7 \mathrm{c}$ & 100.4 & $5.7 \pm 0.6 \mathrm{~d}$ & 10.2 & $6 \pm 2 c$ & 33.3 \\
\hline \multirow{4}{*}{ NSR } & Tr1 & $8.7 \pm 5.5 \mathrm{a}$ & 63.6 & $13.3 \pm 9.9 a$ & 74 & $16 \pm 4 a$ & 25 & $15 \pm 2.7 \mathrm{a}$ & 17.6 & $22 \pm 13 a$ & 59.1 & $25 \pm 13.1 \mathrm{a}$ & 52.3 \\
\hline & $\operatorname{Tr} 2$ & $5.3 \pm 6.7 b$ & 124.8 & $5.7 \pm 5 b$ & 88.8 & $6 \pm 2 b$ & 33.3 & $6.7 \pm 4.9 b$ & 74 & $7.3 \pm 8.4 \mathrm{c}$ & 114.4 & $10 \pm 8.7 \mathrm{c}$ & 86.6 \\
\hline & $\operatorname{Tr} 3$ & $1 \pm 1 d$ & 100 & $3 \pm 3 c$ & 100 & $5 \pm 1.7 \mathrm{~b}$ & 34.6 & $5.7 \pm 2.9 b$ & 50.9 & $11 \pm 4.6 b$ & 41.7 & $11.7 \pm 1.5 \mathrm{a}$ & 13.1 \\
\hline & $\operatorname{Tr} 4$ & $1.7 \pm 0.6 \mathrm{c}$ & 34.6 & $2 \pm 1.73 \mathrm{c}$ & 86.6 & $4 \pm 1 \mathrm{c}$ & 25 & $4.7 \pm 5.7 \mathrm{c}$ & 121.9 & $4.7 \pm 0.6 \mathrm{~d}$ & 12.4 & $5 \pm 2 d$ & 40 \\
\hline \multirow{4}{*}{ NS } & Tr1 & $559 \pm 696 a$ & 124.6 & $272 \pm 241 a$ & 88.7 & $889 \pm 694 a$ & 78.1 & $825 \pm 350 a$ & 42.4 & $2309 \pm 1266 a$ & 54.8 & $2300 \pm 951 \mathrm{a}$ & 41.3 \\
\hline & $\operatorname{Tr} 2$ & $68.3 \pm 13.7 \mathrm{~d}$ & 20 & $56 \pm 21.2 \mathrm{c}$ & 37.8 & $222.7 \pm 119.4 \mathrm{c}$ & 53.6 & $604 \pm 180 \mathrm{~b}$ & 29.7 & $540 \pm 387 d$ & 71.8 & $1176 \pm 817 b$ & 69.5 \\
\hline & $\operatorname{Tr} 3$ & $107.3 \pm 73.8 \mathrm{c}$ & 68.8 & $98.3 \pm 69.4 b$ & 70.6 & $327.3 \pm 89.2 b$ & 27.3 & $467.3 \pm 169.4 \mathrm{c}$ & 36.3 & $1194 \pm 638 b$ & 53.5 & $2299 \pm 1094 a$ & 47.6 \\
\hline & $\operatorname{Tr} 4$ & $154 \pm 72.6 \mathrm{~b}$ & 47.1 & $44.7 \pm 23.7 \mathrm{~d}$ & 53 & $24 \pm 6 c$ & 25 & $380 \pm 263 d$ & 69.1 & $786 \pm 520 c$ & 66.2 & $697 \pm 301 \mathrm{c}$ & 43.2 \\
\hline \multirow{3}{*}{ NB } & Tr1 & $5.7 \pm 5 a$ & 88.8 & $11.7 \pm 12.2 \mathrm{a}$ & 104.7 & $12.7 \pm 8.5 \mathrm{a}$ & 67.1 & $16.7 \pm 9.1 \mathrm{a}$ & 54.4 & $36 \pm 33.2 \mathrm{a}$ & 92.2 & $39.3 \pm 24.2 b$ & 61.6 \\
\hline & $\operatorname{Tr} 2$ & $0.3 \pm 0.6 \mathrm{c}$ & 173.2 & $0.7 \pm 1.2 \mathrm{c}$ & 173.2 & $6 \pm 6.6 c$ & 109.3 & $6.67 \pm 9.1 \mathrm{c}$ & 136.1 & $10 \pm 10.6 \mathrm{c}$ & 105.8 & $21.3 \pm 12.3 \mathrm{c}$ & 57.9 \\
\hline & $\operatorname{Tr} 3$ & $2.3 \pm 2.1 b$ & 89.2 & $4.3 \pm 7.5 b$ & 173.2 & $7.7 \pm 2.1 b$ & 27.2 & $9.3 \pm 3.8 b$ & 40.6 & $18.7 \pm 2.3 b$ & 12.4 & $45.7 \pm 11 \mathrm{a}$ & 24.1 \\
\hline
\end{tabular}




\begin{tabular}{|c|c|c|c|c|c|c|c|c|c|c|c|c|c|}
\hline & $\operatorname{Tr} 4$ & $0 \mathrm{~d}$ & - & $0.3 \pm 0.6 \mathrm{c}$ & 173.2 & $1 \pm 1 \mathrm{~d}$ & 100 & $6.3 \pm 4.2 \mathrm{c}$ & 65.7 & $16.7 \pm 12.7 \mathrm{~b}$ & 76 & $17 \pm 17.1 d$ & 100.4 \\
\hline \multirow{4}{*}{ NL } & Tr1 & $208.7 \pm 164.6 a$ & 78.9 & $532 \pm 301 a$ & 56.5 & $617 \pm 832 a$ & 134.9 & $737 \pm 415 a$ & 56.3 & $1022 \pm 89.4 a$ & 8.7 & $1359 \pm 180 \mathrm{a}$ & 13.2 \\
\hline & $\operatorname{Tr} 2$ & $74.7 \pm 19 \mathrm{c}$ & 25.3 & $78.3 \pm 50 \mathrm{c}$ & 63.5 & $241 \pm 145 \mathrm{c}$ & 60.2 & $449 \pm 383 b$ & 85.4 & $463 \pm 291 c$ & 62.9 & $726 \pm 549 b$ & 75.6 \\
\hline & $\operatorname{Tr} 3$ & $121 \pm 88.1 b$ & 72.8 & $126.7 \pm 101 b$ & 79.7 & $260.3 \pm 46.2 b$ & 17.8 & $427 \pm 177 \mathrm{c}$ & 41.5 & $748 \pm 266 b$ & 35.6 & $1595 \pm 260 \mathrm{a}$ & 16.3 \\
\hline & $\operatorname{Tr} 4$ & $25.7 \pm 11.6 \mathrm{~d}$ & 45.2 & $39.67 \pm 12.7 \mathrm{~d}$ & 31.9 & $97.7 \pm 29 \mathrm{~d}$ & 29.7 & $420 \pm 346 c$ & 82.4 & $534 \pm 435 c$ & 81.3 & $661 \pm 345 b$ & 52.3 \\
\hline
\end{tabular}

Legend : H : Height ; LP : Lenght of pivot ; DC :Diameter at collar ; PD : Pivot diameter ; TNR : Total number of roots ; NSR :Number of side roots ; NS :Number of spines ; NB :Number of branches ; NL :Number of leaves ; Tr1 :substrate containing 1/4 manure and 3/4 sand + watering twice a day; $\operatorname{Tr} 2$ :substrate containing $1 / 4$ manure and $3 / 4$ sand + watering once a week $; \operatorname{Tr} 3:$ substrate containing sand only + watering twice a day $; \operatorname{Tr} 4$ :substrate containing sand only + watering once a week ; A :Average ; CV : Coefficient of variation.

Table 2. Results of Kruskal-Wallis test on measured parameters

\begin{tabular}{|c|c|c|c|c|c|c|c|c|c|c|c|c|c|c|c|c|c|c|c|c|}
\hline Months & Treatments & & $\mathbf{H}$ & & $\mathbf{L P}$ & & DC & & PD & & TNR & & NSR & & NS & & NB & & NL & \\
\hline & & $\mathrm{N}$ & M & V Z & M & V Z & M & V Z & M & V Z & M & V Z & M & V Z & M & V Z & M & V Z & M & V Z \\
\hline \multirow{5}{*}{1} & $\operatorname{Tr} 1$ & 3 & 10.3 & -1.01 & 35 & -0.29 & 0.39 & 1.3 & 0.29 & -0.29 & 19 & 1.8 & 18 & 1.8 & 176 & 1.88 & 9 & 1.52 & 139 & 2.02 \\
\hline & $\operatorname{Tr} 2$ & 3 & 20.8 & 2.6 & 32 & -1.15 & 0.21 & -1.73 & 0.15 & -2.02 & 10 & 0.72 & 9 & 0.72 & 62 & -1.59 & 0 & -1.66 & 68 & -0.58 \\
\hline & $\operatorname{Tr} 3$ & 3 & 7.9 & -1.8 & 24.5 & -2.45 & 0.32 & -1.15 & 0.29 & -1.15 & 2 & -1.59 & 1 & -1.59 & 126 & -0.51 & 3 & -0.36 & 155 & 0.58 \\
\hline & $\operatorname{Tr} 4$ & 3 & 16 & 1.3 & 53.6 & 1.3 & 0.3 & -1.01 & 0.41 & 0.87 & 3 & -0.72 & 2 & -0.72 & 180 & 1.15 & 1 & -1.23 & 104 & 0.14 \\
\hline & P value & & $0.025^{*}$ & & $0.013 *$ & & $0.025 *$ & & $0.034 *$ & & 0.227 & & 0.227 & & 0.146 & & 0.094 & & 0.109 & \\
\hline \multirow{5}{*}{2} & $\operatorname{Tr} 1$ & 3 & 26.3 & 2.31 & 52.5 & -1.15 & 0.32 & 0.87 & 0.27 & 0.87 & 13 & 2.02 & 6 & 1.73 & 166 & 2.31 & 5 & 1.44 & 137 & 2.17 \\
\hline & $\operatorname{Tr} 2$ & 3 & 7.1 & -1.73 & 36.5 & -1.88 & 0.19 & -2.02 & 0.15 & -1.73 & 3 & -0.65 & 2 & -0.65 & 48 & -0.65 & 0 & -1.3 & 58 & 0.36 \\
\hline & $\operatorname{Tr} 3$ & 3 & 19.5 & 1.3 & 53.1 & -0.87 & 0.28 & -0.29 & 0.16 & -1.88 & 5 & 0.29 & 4 & 0.43 & 66 & 0.58 & 0 & -0.29 & 84 & 1.15 \\
\hline & $\operatorname{Tr} 4$ & 3 & 10.7 & -0.29 & 65.7 & 1.88 & 0.23 & -1.15 & 0.25 & 0.14 & 4 & -0.87 & 3 & -0.72 & 32 & -1.73 & 0 & -1.3 & 42 & -1.52 \\
\hline & P value & & $0.039 *$ & & $0.032 *$ & & $0.033^{*}$ & & $0.024 *$ & & 0.301 & & 0.422 & & 0.112 & & 0.161 & & $0.032 *$ & \\
\hline \multirow{5}{*}{3} & $\operatorname{Tr} 1$ & 3 & 45 & 2.31 & 67.3 & 1.3 & 0.42 & 0.07 & 0.47 & 0 & 17 & 2.17 & 16 & 2.6 & 850 & 2.02 & 16 & 1.44 & 956 & 2.17 \\
\hline & $\operatorname{Tr} 2$ & 3 & 41 & 1.59 & 60 & -1.2 & 0.35 & -0.4 & 0.33 & -0.9 & 6 & 0.07 & 5 & -0.1 & 178 & 0.43 & 5 & 0 & 183 & 0.58 \\
\hline & $\operatorname{Tr} 3$ & 3 & 36 & 0 & 63.5 & 0.43 & 0.45 & 0.36 & 0.44 & -0.1 & 5 & 0.36 & 4 & 0.22 & 334 & 1.44 & 11 & 1.08 & 286 & 1.15 \\
\hline & $\operatorname{Tr} 4$ & 3 & 6.3 & -2.3 & 66.1 & 1.08 & 0.17 & -2.6 & 0.42 & -1.6 & 4 & -1.7 & 3 & -1.7 & 24 & -2.6 & 0 & -2.4 & 20 & -1.6 \\
\hline & P value & & $0.014 *$ & & 0.225 & & $0.025 *$ & & 0.09 & & 0.141 & & 0.068 & & $0.019 *$ & & 0.115 & & $0.023 *$ & \\
\hline 4 & $\operatorname{Tr} 1$ & 3 & 62 & 2.31 & 87.1 & 0.87 & 0.76 & 0.58 & 0.66 & 0.58 & 14 & 1.37 & 14 & 2.02 & 952 & 1.73 & 13 & 1.23 & 595 & 1.15 \\
\hline
\end{tabular}




\begin{tabular}{|c|c|c|c|c|c|c|c|c|c|c|c|c|c|c|c|c|c|c|c|c|}
\hline & $\operatorname{Tr} 2$ & 3 & 55.6 & 1.15 & 80.6 & -0.3 & 0.59 & -0.9 & 0.6 & 0 & 4 & -0.4 & 3 & -0.6 & 534 & 1.15 & 6 & -0.7 & 456 & 0.43 \\
\hline & $\operatorname{Tr} 3$ & 3 & 53.8 & 0.43 & 65.8 & -1.7 & 0.55 & -1.3 & 0.56 & -0.6 & 4 & -1.5 & 3 & -1.6 & 410 & -0.3 & 7 & -0.9 & 348 & 0.43 \\
\hline & $\operatorname{Tr} 4$ & 3 & 19.2 & -1.6 & 82.1 & 0 & 0.61 & -1 & 0.3 & -2.6 & 5 & -1 & 4 & -1 & 368 & -1 & 5 & -1.4 & 380 & 0.29 \\
\hline & $P$ value & & $0.019 *$ & & 0.388 & & 0.075 & & $0.023 *$ & & 0.172 & & 0.112 & & 0.173 & & 0.183 & & 0.223 & \\
\hline & $\operatorname{Tr} 1$ & 3 & 88 & 1.88 & 92.6 & -0.5 & 0.99 & 1.15 & 1 & 1.3 & 35 & 2.6 & 31 & 1.8 & 2388 & 2.02 & 29 & 2.31 & 976 & 2.31 \\
\hline & $\operatorname{Tr} 2$ & 3 & 75.8 & 1.3 & 92 & 0 & 0.74 & -0.4 & 0.7 & -0.7 & 16 & -0.4 & 15 & 0 & 462 & -1.3 & 3 & -1.8 & 364 & -0.9 \\
\hline 5 & $\operatorname{Tr} 3$ & 3 & 72 & 0.72 & 83 & -2 & 0.5 & -1.9 & 0.48 & -1.7 & 10 & 0 & 10 & 0.22 & 1365 & 1.01 & 20 & 0.22 & 695 & 0.87 \\
\hline & $\operatorname{Tr} 4$ & 3 & 24.8 & -1.9 & 90.3 & 0.43 & 0.54 & -1.4 & 0.6 & -1.4 & 6 & -2 & 5 & -2 & 1068 & -0.3 & 12 & -0.5 & 570 & -0.6 \\
\hline & P value & & $0.031 *$ & & 0.154 & & $0.025 *$ & & $0.024 *$ & & 0.062 & & 0.2 & & 0.127 & & 0.126 & & 0.087 & \\
\hline & $\operatorname{Tr} 1$ & 3 & 114 & 2.6 & 128 & 1.73 & 1.3 & 0.87 & 1.37 & 0.58 & 16 & 2.6 & 15 & 2.6 & 2352 & 1.59 & 40 & 0.58 & 1386 & 1.44 \\
\hline & $\operatorname{Tr} 2$ & 3 & 93.5 & 0.87 & 125 & 0.72 & 0.99 & -1.6 & 1.06 & -1 & 7 & -1.4 & 6 & -1.4 & 1644 & -0.3 & 18 & -0.3 & 747 & -0.6 \\
\hline 6 & $\operatorname{Tr} 3$ & 3 & 92.4 & 0.43 & 101 & -2.2 & 1.08 & 0.43 & 1.3 & 0.29 & 13 & 1.08 & 12 & 1.08 & 1825 & 1.73 & 51 & 1.88 & 1563 & 2.31 \\
\hline & $\operatorname{Tr} 4$ & 3 & 27.3 & -1.3 & 123 & -0.3 & 0.7 & -2.3 & 0.42 & -2.5 & 6 & -2.2 & 5 & -2.2 & 640 & -1.3 & 12 & -1.2 & 775 & -0.6 \\
\hline & $P$ value & & $0.012 *$ & & 0.157 & & $0.014 *$ & & $0.023 *$ & & $0.017 *$ & & $0.017 *$ & & 0.083 & & 0.284 & & $0.018 *$ & \\
\hline
\end{tabular}

Legend: H : Height ; LP : Lenght of pivot ; DC :Diameter at collar ; PD : Pivot diameter ; TNR : Total number of roots ; NSR :Number of side roots ; NS :Number of spines ; NB :Number of branches ; NL :Number of leaves

* Significant probability at the threshold of $\alpha \leq 0.05$.

Table 3. Comparaison of the average measured parameters (Levene Test)

\begin{tabular}{|c|c|c|c|c|c|c|c|c|c|c|c|c|c|c|}
\hline \multirow[b]{2}{*}{ Variables } & \multirow[b]{2}{*}{ DDL1 } & \multicolumn{2}{|c|}{ Months } & \multicolumn{2}{|c|}{1} & \multicolumn{2}{|l|}{2} & \multirow{2}{*}{$\begin{array}{c}\mathbf{3} \\
\operatorname{Pr}(>\mathbf{F})\end{array}$} & \multicolumn{2}{|r|}{4} & \multicolumn{2}{|c|}{5} & \multicolumn{2}{|c|}{6} \\
\hline & & $\overline{\text { DDL2 }}$ & F value & $\operatorname{Pr}(>\mathbf{F})$ & F value & $\operatorname{Pr}(>\mathbf{F})$ & F value & & F value & $\operatorname{Pr}(>F)$ & F value & $\operatorname{Pr}(>\mathrm{F})$ & F value & $\operatorname{Pr}(>\mathbf{F})$ \\
\hline Height & 4 & 10 & 0.4533 & 0.768 & 1.7444 & 0.217 & 3.7458 & $0.041 *$ & 2.0123 & 0.169 & 3.5375 & $0.048^{*}$ & 4.233 & $0.029 *$ \\
\hline Length of the pivot & 4 & 10 & 1.5372 & 0.264 & 4.5373 & $0.024 *$ & 2.5544 & 0.104 & 4.4324 & $0.026^{*}$ & 3.4102 & 0.053 & 3.7085 & $0.042 *$ \\
\hline Diameter at collar & 4 & 10 & 9.2881 & $0.002 *$ & 5.5588 & $0.013 *$ & 10.849 & $0.001 * * *$ & 3.5201 & $0.048 *$ & 2.4421 & 0.115 & 2.9717 & 0.073 \\
\hline Pivot diameter & 4 & 10 & 15.688 & $<0.001 * * *$ & 3.0234 & 0.071 & 4.9 & $0.019 *$ & 4.6666 & $0.022 *$ & 0.7988 & 0.553 & 2.3349 & 0.12 \\
\hline Total number of roots & 4 & 10 & 6.3501 & $0.008 *$ & 3.1972 & 0.062 & 1.2121 & 0.365 & 4.6207 & $0.023 *$ & 4.1897 & $0.030 *$ & 10.79 & $0.001 * * *$ \\
\hline Number of sideroots & 4 & 10 & 6.6417 & $0.007 *$ & 3.685 & $0.043 *$ & 0.7845 & 0.561 & 5.2324 & $0.015^{*}$ & 5.3546 & $0.014 *$ & 10.79 & $0.001 * * *$ \\
\hline Number of spines & 4 & 10 & 13.331 & $<0.001 * * *$ & 9.8359 & $0.002 *$ & 3.9284 & $0.036 *$ & 1.6148 & 0.245 & 1.5949 & 0.25 & 2.4666 & 0.112 \\
\hline Number of branches & 4 & 10 & 6.074 & $0.009 * *$ & 5.7414 & $0.012 *$ & 5.0833 & $0.017 *$ & 5.1063 & $0.017 *$ & 5.166 & $0.016^{*}$ & 2.0661 & 0.16 \\
\hline Number of leaves & 4 & 10 & 14.476 & $<0.001 * * *$ & 7.5376 & $0.005 * *$ & 11.586 & $<0.001 * * *$ & 0.7957 & 0.554 & 1.8614 & 0.194 & 2.01 & 0.169 \\
\hline
\end{tabular}

Significant probabilities: $* \mathrm{P}<0.05 . * * \mathrm{P}<0.01$ and $* * * \mathrm{P}<0.001$. 


\section{References:}

1. Abdallah, F., Noumi Z., Ouled-Belgacem A., Michalet R., Touzard B. And Chaieb, M. (2012). The influence of Acacia tortilis (Forssk.) subsp. raddiana (Savi) Brenan presence, grazing, and water availability along the growing season, on the understory herbaceous vegetation In southern Tunisia. Journal Of Arid Environments, 76 (0): 105-114

2. Abdallah, F., Noumi, Z., Touzard, B., Belgacem, A. O., Neffati, M. and Chaieb,M. (2008). The influence of Acacia tortilis (forssk.) subsp. raddiana (savi) and livestock grazing on grass species composition, yield and soil nutrients in arid environments of south Tunisia. Flora Morphology, Distribution, Functional Ecology of Plants, 203(2): 116125.

3. Abdourhamane, H., Dan Guimbo, I., Morou, B., Mahamane, A. (2014). Potential germination and initial growth of Sclerocarya birrea (A. Rich.) Hochst, in Niger. Journal of Applied Biosciences, 76 : 6433- 6443.

4. Amani, A., Inoussa, M.M, Dan Guimbo, I., Mahamane, A., Saadou, M. \&Lykke A.M. (2015). Germination et croissance de quatre espèces de Combretaceae en pépinière. Tropicultura, 33 : (2)135-145.

5. Andersen, G. L., and Krzywinski, K. (2007a). Longevity and growth of Acacia tortilis; insights from 14c content and anatomy of wood. BMC Ecol7: 4.

6. Andersen, G. L., and Krzywinski, K. (2007b). Mortality, recruitment and change of desert tree populations in a hyper-arid environment. Plos ONE 2 (2) : E208.

7. Arbonnier, M.(2004). Trees, shrubs and lianas of West African dry zones. CIRAD, Margraf Publishers Gmbh, MNHN, Paris, France, 573 pp.

8. Baghdadi, H., et Sahouli S. (2003). Contribution à l'étude de la multiplication de pistachier de l'Atlas : Pistacia atlantica Desf. par semis et par voie in vitro. Mémoire d'ingénieur d'état en biotechnologie végétale, université des sciences et de la technologie, Oran, 60p.

9. Benmahioul, B., Khelil, B., Kaïd-Harche, M., Daguin, F. (2010). Étude de la germination et de l'effet du substrat sur la croissance de jeunes semis de Pistaciavera L. Acta Botanica Malacitana, 35: 107-114.

10. Bille, J.C. (1977). Etude de la production primaire nette d'un écosystème sahélien. Travaux et Doc., ORSTOM Ed., Paris, 82p.

11. Boulain, N. (2004). Effet des facteurs climatiques et anthropiques dans l'évolution récente des écosystèmes tropicaux : modélisation spatialisée du bilan hydrique d'un petit bassin versant sahélien. Thèse de doctorat en ??? . Université Pierre et Marie Curie - Paris VI, 171p. 
12. Bowie, M., and Ward D. (2004). Water and nutrient status of the mistletoe plicosepalusacaciae parasitic on isolated negev desert populations of Acacia raddiana differing in level of mortality. Journal Of Arid Environments, 56 (3) : 487-508.

13. CNEDD (2011) : Évaluation des impacts climatiques sur les forets au Niger. Rapport final, 50p.

14. Diouf, M., Akpo, L.E., Rocheteau, A., Do, F.C., Goudiaby, V., Diagne, A.L. (2002). Dynamique du peuplement ligneux d'une végétation sahélienne au nord Sénégal (Afrique de l'Ouest); Journal des Sciences. 2 (1): 1-9.

15. Diouf, M., Do, F.C., Akpo, L.E., Goudiaby, V., Rocheteau, A. (2004). Variations spatiales de la structure spécifique d'un peuplement ligneux en milieu sahélien (Ferlo, Nord - Sénégal). Ann. Bot. Afr. O., 03: 7586.

16. Diouf, M., Logbo, J., Do, F.C., et Akpo, L.E. (2013). Déterminisme de la feuillaison de Acacia tortilis (Forsk.) dans la réserve sylvopastorale de Sogobé, Ferlo, Nord-Sén ; Int. J. Biol. Chem. Sci. 7(5) : 2106-2116

17. Fterich, A., Mahdhi, M., Lafuente, A., Pajuelo, E., Caviedes, M. A., Rodriguez-Lorente, I. D. and Mars M. (2012). Taxonomic and symbiotic diversity of bacteria isolated from nodules of Acacia tortilis subsp. raddiana in arid soils of Tunisia. Canadian Journal OfMicrobiology, 58(6) : 738-751.

18. Ganaba, S. (1994). Rôle des structures racinaires dans la dynamique du peuplement ligneux de la région de la Mare d'Oursi entre 1980 et 1994. Thèse doctorat 3e cycle en Biologie et Écologie Végétales, Univ. De Ouagadougou. 140 p.

19. Gonzalez, P., Tucker, C.J., Sy, H., 2012. Tree density and species decline in the African Sahel attributable to climate. Journal of Arid Environments, 78 : 55-64.

20. Hopmans, J.W., Bristow K.L. (2002). Current capabilities and future needs of root water and nutrient uptake modeling. Adv. Agro., 85 : 103-183.

21. Issa, A., Mahamane, A., Tidjani, A.D, Zakarou, G., Issaka, A. (2009). Dnse du Niger : État de référence des observatoires de Diffa, Zinder, Azawad et Torodi-Tondikandia, 131p.

22. Jackson, R.B., Sperry, J.S., Dawson, T.E. (2000). Root water uptake and transport: using physiological processes in global predictions. Trends in Plant Sciences, 5, 482-488.

23. Kane, I. (1996). Influence de l'alimentation en eau sur la croissance et le fonctionnement hydrique de jeunes plants d'Acacia. Application à 3 espèces au Sénégal : Acacia tortilis (Forsk.) Hayne subsp. raddiana 
(Savi) Brenan; Acacia senegal (L) Wild ; Acacia dudgeoni Craib. Ex Holl. Thèse de 3e cycle en ?????, UCAD de Dakar.

24. Laminou, M. O. (2009). Fixation des dunes dans le sud-est du Niger : évaluation de l'efficacité de la barrière mécanique, espèces ligneuses adaptées et potentialités d'inoculation mycorhizienne. Thèse de doctorat en Sciences Agronomiques et Ingénierie Biologique, Université de Liège. 158p.

25. LE Floc'h, E., et Grouzis, M. (2003). Acacia raddiana, un arbre des zones arides à usages multiples. Un arbre au désert :Acacia raddiana. Éd. IRD Paris (France).21-58

26. Logbo, J., Diouf M., Ngaryo, T.F., Ameglio, T., Akpo L.E. (2013). Effet du stress hydrique sur l'architecture racinaire de jeunes plants de Acacia tortilis (Forsk.), de Balanites aegyptiaca (L) Del., et de Zizyphus mauritiana Lam. Int. J. Biol. Chem. Sci., 7(3) :1011-1033.

27. Münzbergová, Z., and Ward, D. (2002). Acacia trees as keystone species in Negev desert ecosystems. Journal of Vegetation Science, $13: 227-236$.

28. Noumi, Z., and Chaieb M. (2012). Dynamics of Acacia tortilis (forssk.) hayne subsp. raddiana (savi) brenan in arid zones of Tunisia. Acta BotanicaGallica 159 (1) : 121-126.

29. Noumi, Z. (2010). Acacia tortilis (Forssk.) Hayne subsp. raddiana (Savi) Brenan en Tunisie pré-saharienne : structure du peuplement, réponses et effets biologiques et environnementaux. Thèse de doctorat en Écologie évolutive, fonctionnelle et des communautés, Faculté des sciences de Sfax, 251p.

30. Noumi, Z., Touzard, B., Michalet, R., et. Chaieb, M. (2010). The effects of browsing on the structure of Acacia tortilis (Forssk.) Hayne ssp. raddiana (Savi) Brenan along a gradient of water availability in arid zones of Tunisia. Journal of Arid Environments 74(6):625-631.

31. Ozer, A., et Ozer, P. (2005). Désertification au Sahel : crise climatique ou anthropique. Bulletin des Séances de l'Académie royale des sciences d'Outre-Mer, $51: 395-423$.

32. Rabiou, H., Diouf, A., Bationo, B. A., Segla, K. N., Mahamane, A., Adjonou K., Kokou K., Kokutse A. D., Saadou M. (2015). Structure des peuplements naturels de Pterocarpus erinaceus dans le domaine soudanien, au Niger et au Burkina Faso. Bois et forêts des tropiques, 325 (3) : 1-13.

33. Salif, B. (2001). Caractérisation moléculaire de la diversité symbiotique des souches isolées de Acacia tortilis subsp. raddiana. Thèse de doctorat en génétique moléculaire, Université de Cheikh Anta Diop Dakar, 147p. 
34. Sambou, B. (2004). Évaluation de l'état de la dynamique et des tendances évolutives de la flore et de la végétation ligneuses dans les domaines soudanien et sub-guinéen au Sénégal. Thèse de doctorat en biologie appliquée, Université Cheikh Anta Diop, 248p.

35. Vassal, J. (2003). Introduction In Grouzis, M. and Floc'H, L. (eds.), Un arbre au désert, Acacia raddiana. Paris : IRD Editions, 13-17.

36. Vroh, Bi Tra A., Adou, Yao, C. Y., Kouamé, D., N'da Dibi, H., N'guessan, K. E. (2010). Diversités floristique et structurale sur le site d'une réserve naturelle volontaire à Azaguié, Sud-est de la Côte d'Ivoire. European Journal of Scientific Research,45(3) : 1450-216 